\title{
Scientific results from Gulf of Mexico Gas Hydrates Joint Industry Project Leg 1 drilling: Introduction and overview
}

\author{
C. Ruppel ${ }^{\mathrm{a}, *}$, R. Boswell ${ }^{\mathrm{b}, 1}$, E. Jones ${ }^{\mathrm{c}, 2}$ \\ ${ }^{a}$ U.S. Geological Survey, 384 Woods Hole Road, Woods Hole, MA 02543, USA \\ ${ }^{\mathrm{b}}$ National Energy Technology Laboratory, U.S. Dept. of Energy, 3610 Collins Ferry Road, P.O. Box 880, Morgantown, WV 26507-0880, USA

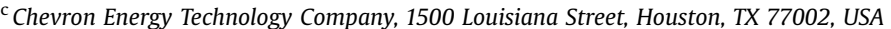

\section{A R T I C L E I N F O}

\section{Article history:}

Received 18 February 2008

Accepted 19 February 2008

\section{Keywords:}

Gas hydrate

Hazard

Ocean drilling

Borehole

Gulf of Mexico

\begin{abstract}
A B S T R A C T
The Gulf of Mexico Gas Hydrates Joint Industry Project (JIP) is a consortium of production and service companies and some government agencies formed to address the challenges that gas hydrates pose for deepwater exploration and production. In partnership with the U.S. Department of Energy and with scientific assistance from the U.S. Geological Survey and academic partners, the JIP has focused on studies to assess hazards associated with drilling the fine-grained, hydrate-bearing sediments that dominate much of the shallow subseafloor in the deepwater $(>500 \mathrm{~m}$ ) Gulf of Mexico. In preparation for an initial drilling, logging, and coring program, the JIP sponsored a multi-year research effort that included: (a) the development of borehole stability models for hydrate-bearing sediments; (b) exhaustive laboratory measurements of the physical properties of hydrate-bearing sediments; (c) refinement of new techniques for processing industry-standard 3-D seismic data to constrain gas hydrate saturations; and (d) construction of instrumentation to measure the physical properties of sediment cores that had never been removed from in situ hydrostatic pressure conditions. Following review of potential drilling sites, the JIP launched a 35-day expedition in Spring 2005 to acquire well logs and sediment cores at sites in Atwater Valley lease blocks 13/14 and Keathley Canyon lease block 151 in the northern Gulf of Mexico minibasin province. The Keathley Canyon site has a bottom simulating reflection at $\sim 392 \mathrm{~m}$ below the seafloor, while the Atwater Valley location is characterized by seafloor mounds with an underlying upwarped seismic reflection consistent with upward fluid migration and possible shoaling of the base of the gas hydrate stability (BGHS). No gas hydrate was recovered at the drill sites, but logging data, and to some extent cores, suggest the occurrence of gas hydrate in inferred coarser-grained beds and fractures, particularly between 220 and $330 \mathrm{~m}$ below the seafloor at the Keathley Canyon site. This paper provides an overview of the results of the initial phases of the JIP work and introduces the 15 papers that make up this special volume on the scientific results related to the 2005 logging and drilling expedition.
\end{abstract}

Published by Elsevier Ltd.

\section{Introduction}

Gas hydrate is an ice-like substance that forms in marine sediments when water at relatively low temperatures and at pressures greater than $\sim 5 \mathrm{MPa}$ combines with methane or other low molecular weight gases present in excess of their local solubility. Such conditions typically occur within the upper tens to hundreds of meters of the sedimentary section at water depths greater than $\sim 500 \mathrm{~m}$. For decades, most offshore exploration for oil and conventional natural gas reserves has been conducted at water depths

\footnotetext{
* Corresponding author. Tel.: +1 508457 2339; fax: +1 5084572310.

E-mail addresses: cruppel@usgs.gov (C. Ruppel), ray.boswell@netl.doe.gov

(R. Boswell), ejones@chevron.com (E. Jones).

1 Tel.: +13042854541.

2 Tel.: +1 8327216141 .
}

in which gas hydrate is not expected to be present in the shallow sedimentary section. Driven by the strong, continued demand for these resources and enabled by key technological advances, energy companies are increasingly drilling deepwater ( $>500 \mathrm{~m}$ water depth) wells that must safely penetrate (or avoid) the gas hydrate zone to reach deeper targets.

Commercial activities that disrupt hydrate-bearing sediments or sediments charged with free gas beneath the gas hydrate stability zone (GHSZ) could encounter numerous potential hazards, as summarized by Hovland and Gudmestad (2001) and shown in Fig. 1. One concern has been that perturbations to temperature or pressure conditions might provoke gas hydrate dissociation and unexpected gas and/or water flows into wellbores, causing costly delays or perhaps even the loss of the hole. Overpressured free gas accumulations trapped below gas hydrate-bearing sediments might present similar hazards if penetrated by drilling. The 


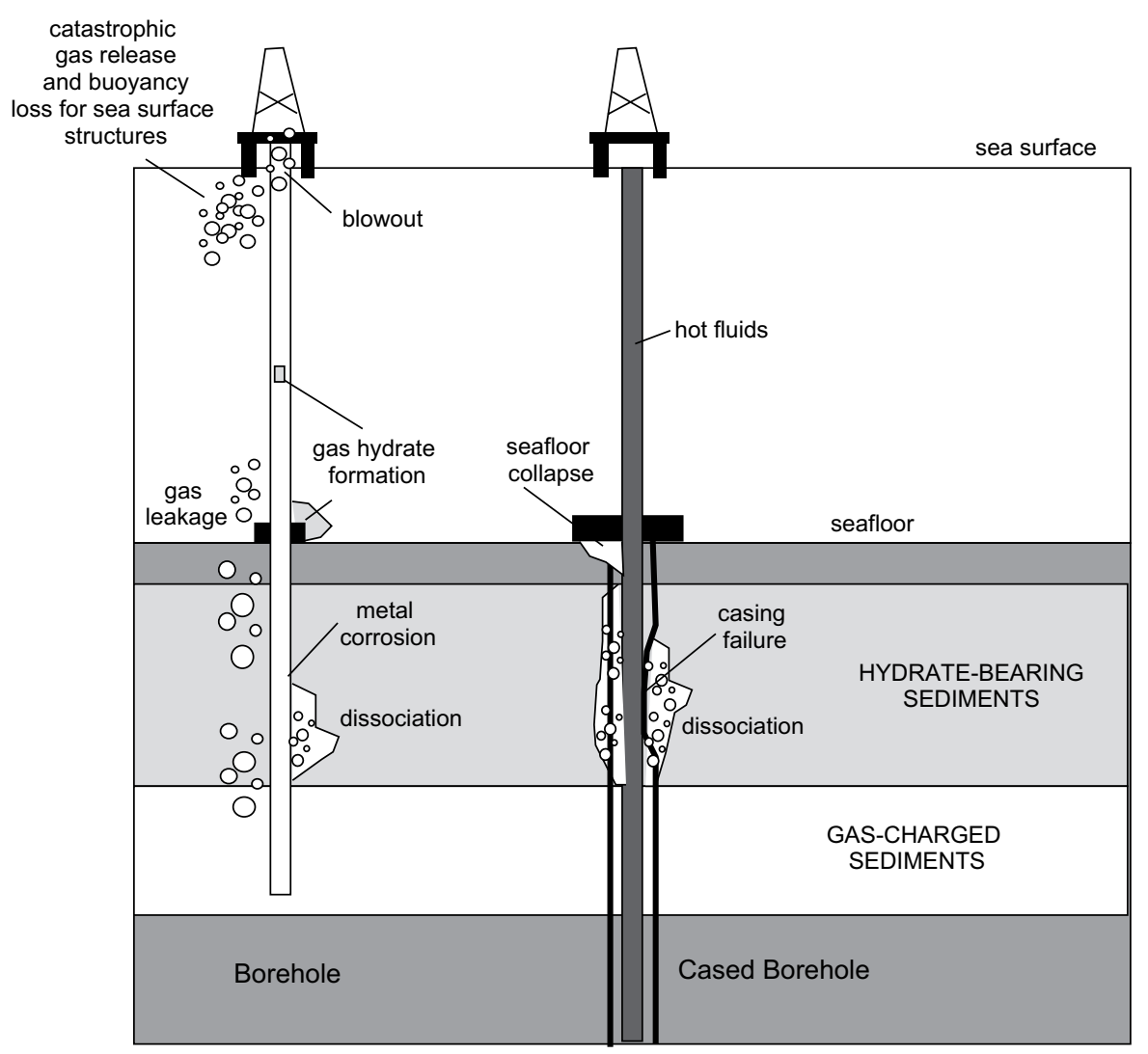

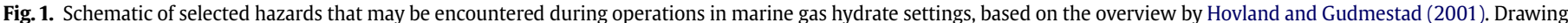

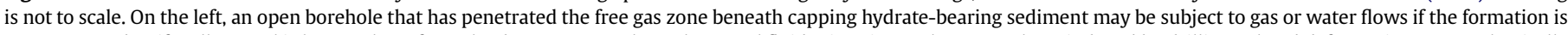

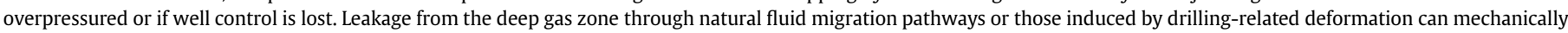

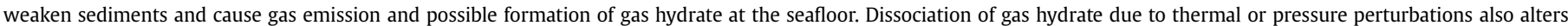

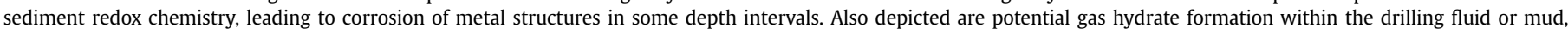

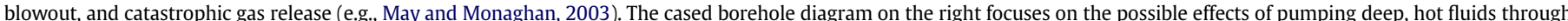

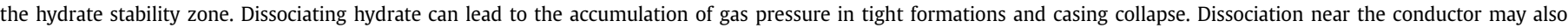
mechanically weaken the seafloor and undermine infrastructure.

dissociation of gas hydrate near the seafloor could lead to seafloor collapse and loss or damage to infrastructure, including pipelines, bottom hole assemblies, templates, and anchors or piles supporting manned sea surface facilities. This hazard also remains during the post-drilling production phase, when production of warm fluids from deep reservoirs might induce gas hydrate dissociation, reduce formation competence, and cause the collapse of casing or a loss of casing integrity. In low permeability sediments with no pathways for gas migration, dissociation of gas hydrate could raise pressures enough to damage casing. Catastrophic release of gas from drilling overpressured gas-charged formations without careful well control or from massive dissociation of gas hydrate could in theory release enough gas into the water column that sea surface facilities or tender ships lose their buoyancy (May and Monaghan, 2003). Although the JIP focused only on natural occurrences of gas hydrate, formation of gas hydrate on instrumentation at the seafloor, within pipes, or in drilling mud is also a hazard that has been addressed by the energy sector for decades.

A paucity of basic data on the nature and behavior of gas hydrate bearing sediments has rendered it difficult to assess or constrain many of these hazards. Standard industry practice has been completion of a shallow drilling hazard survey prior to locating deepwater wells and strict avoidance of locations where hydrate-related hazards were suspected. With the ever-mounting importance of deepwater targets, such an approach has grown cumbersome and expensive. To this end, a key goal of the Gulf of Mexico Gas Hydrates Joint Industry Project (JIP) was the completion of laboratory, numerical modeling, and field-based studies that would provide better information about the features or conditions that could present legitimate hazards and the best approach to avoid or address such hazards.

The Gulf of Mexico Gas Hydrates JIP was formed in 2001 under the management of Chevron and with the participation of ConocoPhillips, Total, Schlumberger, Halliburton, Reliance Industries, the Japan Oil Gas and Minerals Economic Corporation, and the U.S. Minerals Management Service. The JIP, in collaboration with the DOE and with scientific advice from the U.S. Geological Survey (USGS) and academic researchers at Scripps Institute of Oceanography, Rice University, and Georgia Institute of Technology (Georgia Tech) devised a research plan designed to address uncertainties in the nature of gas hydrate occurrence and associated hazards through (a) fundamental studies to develop the tools and knowledge for assessment of the concentration and distribution of gas hydrate prior to drilling and for predicting the potential consequences of drilling through hydrate-bearing sediments; and (b) a drilling program to acquire exhaustive field data needed for testing and refining predictive models and reconciling laboratory, seismic inversion, and logging results.

\section{Fundamental JIP studies}

JIP activities during the initial years of the project focused on laboratory studies of hydrate-bearing sediments, numerical simulations of borehole stability, the development of new tools for 
analysis of cores retrieved during later drilling phases, processing of existing seismic data and other field data to support the selection of test sites, and the formulation of a field data acquisition program for the logging and coring phase.

Early on, the JIP recognized that knowledge of the mechanical, electrical, and thermal properties of hydrate-bearing sediments would be critical for understanding potential hydrate-related hazards. Yet no single laboratory had ever undertaken a systematic study of the properties of hydrate-bearing sediment across a range of hydrate saturations and grain sizes that typify the shallow sedimentary section in the Gulf of Mexico. To address this knowledge gap, Georgia Tech researchers conducted an exhaustive series of measurements on sand, precipitated silt, crushed silt, and clay sediments subject to different confining pressures and having various concentrations of gas hydrate (Lee, 2007; Martin, 2005; Santamarina et al., 2004; Santamarina and Ruppel, 2008b; Yun et al., 2005, 2007). Waite et al. (2005) also conducted thermal properties measurements in support of the hydrate-bearing sediment characterization effort. Table 1 summarizes the experimental parameters for the Georgia Tech hydrate-bearing sediment studies and the types of data produced. The need to closely control hydrate saturations and to complete the experiments more quickly than is possible when methane hydrate is grown from the aqueous phase in the laboratory led to the decision by the JIP to use synthetic hydrate of tetrahydrofuran (THF) for these experiments. THF is completely miscible with water and forms hydrate only from the aqueous phase, much as gas hydrate probably forms in marine sediments in nature (Zatsepina and Buffett, 2003). In addition to producing exhaustive data on hydrate-bearing sediment for use by the JIP, an important outcome of the laboratory effort was the recognition that the hydrate formation method (from gaseous phase, from aqueous phase, or using the ice method of Stern et al. (1996)) significantly affects the microstructural relationship between hydrate and sediment grains and therefore in part determines particularly the small- and large-strain mechanical properties of hydrate-bearing sediment (Lee et al., 2007; Yun et al., 2007; Santamarina and Ruppel, 2008b).

Table 1

Sediments used, confining pressures applied, target saturations of THF hydrate tested, and parameters determined by the Georgia Tech laboratory program that used standard geotechnical devices to systematically study the properties of hydrate-bearing sediments that are widespread in marine systems.

\begin{tabular}{|c|c|c|c|c|c|}
\hline Sediment & $\begin{array}{c}\text { Specific } \\
\text { surface } \\
\left(\mathrm{m}^{2} / \mathrm{g}\right)\end{array}$ & $\begin{array}{c}\text { Grain } \\
\text { size } \\
D_{50} \\
(\mu \mathrm{m})^{\mathrm{a}}\end{array}$ & \multicolumn{2}{|c|}{$\begin{array}{c}\text { Target saturations } \\
\text { of } \mathrm{THF} \text { hydrate } \\
\text { ( } \% \text { of } \\
\text { pore space) }\end{array}$} & $\begin{array}{c}\text { Confining } \\
\text { pressures } \\
(\mathrm{MPa})\end{array}$ \\
\hline Sand (F110) & 0.019 & 120 & \multicolumn{2}{|c|}{0} & 0 \\
\hline Precipitated silt & 6 & 20 & \multicolumn{2}{|c|}{50} & \\
\hline Crushed silt & 0.113 & 20 & \multicolumn{2}{|c|}{100} & 1.0 \\
\hline Clay (kaolinite) & 36 & 1.1 & & & 2.0 \\
\hline \multicolumn{4}{|c|}{ Mechanical Properties $e^{b, c, d}$} & \multicolumn{2}{|c|}{ Electrical Properties $^{\mathrm{b}}$} \\
\hline Small-strain & \multicolumn{3}{|c|}{ Large-strain } & \multicolumn{2}{|c|}{$\begin{array}{l}\text { Electrical resistivity } \\
\text { - Real permittivity at } 0.2 \\
\text { to } 1.3 \mathrm{GHz}\end{array}$} \\
\hline $\begin{array}{l}\text { - P-wave velocity } \\
\text { > Constrained modulus } \\
\text { > Longitudinal } \\
\text { mechanical impedance } \\
\text { - S-wave velocity } \\
\text { > Shear modulus } \\
\text { > Shear mechanical } \\
\text { impedance } \\
\text { - Dynamic bulk modulus } \\
\text { - Volume change with } \\
\text { phase transformation }\end{array}$ & \multicolumn{3}{|c|}{$\begin{array}{l}\text { - Static bulk modulus } \\
\text { - Triaxial compaction } \\
\text { coeffient } \\
\text { - Young's modulus } \\
\text { - Uniaxial volume } \\
\text { compaction }\end{array}$} & \multicolumn{2}{|c|}{$\begin{array}{l}\text { - Thermal conductivity } \\
\text { Observational }{ }^{\mathrm{c}, \mathrm{f}} \\
\text { - Hydrate distribution } \\
\text { (optical/visual)-pore vs } \\
\text { grain boundary }\end{array}$} \\
\hline
\end{tabular}

The program and its findings are summarized by Santamarina et al. (2004) and Santamarina and Ruppel (2008a) respectively. Not all properties could be determined for all combinations of sediments, confining pressures, or target saturations. Properties denoted by ">" are determined indirectly from the corresponding seismic velocities.

${ }^{a} \mathrm{D}_{50}$ denotes the grain size for which $50 \%$ of the grains are smaller and $50 \%$ larger.

bee, 2007; ' Yun et al., 2005; ${ }^{\mathrm{d}}$ Yun et al., 2007; ${ }^{\mathrm{e}}$ Martin 2005; f Lee et al., 2007
Another critical component of studies conducted by the JIP in advance of the drilling expedition was borehole stability modeling that was in part informed by the Georgia Tech laboratory data. These models, developed by researchers at Schlumberger, focused on determining the impact of disturbing hydrate-bearing sediments during drilling (e.g., Birchwood et al., 2007) and involved a consideration of both sediment geomechanics and the evolution of thermal conditions. Controlling the rate of drilling fluid circulation emerged from the borehole stability models as the critical factor for hazard mitigation (Fig. 2). In particular, increased residence time of the drilling fluid in the section of the drill pipe surrounded by cold seawater was predicted to cool the fluid and to significantly inhibit gas hydrate dissociation once the fluid was circulated in the formation (Birchwood et al., 2007).

A third fundamental effort during the pre-drilling phase of the JIP was the development of new seismic processing and inversion techniques to infer gas hydrate concentrations from conventional 3-D seismic data (Dai et al., 2004; Xu et al., 2004; Dai et al., Part I, 2008). Such seismic surveys have been completed in most parts of the Gulf of Mexico and other petroleum basins to guide exploration for deep conventional oil and gas targets and therefore provide excellent coverage. 3-D surveys are typically designed to provide seismic penetration to several kilometers beneath the seafloor, leading to poor resolution of the details in the shallow subseafloor section of most relevance for gas hydrate studies. While new highresolution seismic data (e.g., Wood et al., 2008) could be acquired to provide better subseafloor images for gas hydrate geohazard surveys, this strategy is generally not efficient or practical. Reprocessing of existing 3-D data to focus on the shallow subseafloor (approximately uppermost $1 \mathrm{~km}$ ) enhances features associated with gas hydrate or free gas, as demonstrated by Dai et al. (Part I, 2008). Analysis of the quantitative characteristics of the reprocessed seismic data using rock physics formulations and inferences

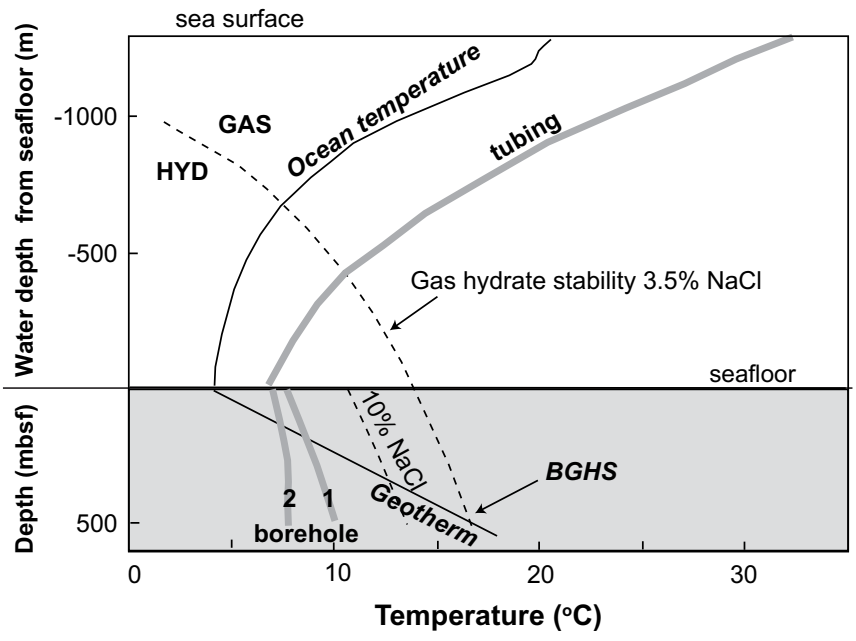

Fig. 2. Results of numerical modeling of temperature perturbations during drilling, adapted from Birchwood et al. (2007) and based on their borehole stability modeling. The black curves denote the temperature structure in the seafloor and the ocean, here assumed to be $1300 \mathrm{~m}$ deep as at the Atwater Valley and Keathley Canyon sites. The dashed curves show the theoretical methane hydrate stability boundary for equilibrium with normal seawater $(3.5 \% \mathrm{NaCl})$ and higher salinity water $(10 \% \mathrm{NaCl})$ that might be encountered in the pores of the shallow subseafloor in the Gulf of Mexico. HYD (hydrate) and GAS (free gas) indicate the stable phase for methane not dissolved in pore waters in the pressure-temperature regions shown. Gray curves represent calculated temperatures for the tubing circulating the drilling fluid in the ocean and for the borehole wall in the seafloor at time 1 (beginning of circulation) and later time 2 (after two hours of circulation at 350 gallons per minute). In this case, the borehole temperature always remains within the gas hydrate stability field. Higher rates of circulation lead to warmer initial temperatures and the potential for at least part of the borehole to be outside the gas hydrate stability field during part of the circulation regime. 
about lithology then permit estimation of gas hydrate saturations. When available, borehole logs-particularly sonic, resistivity, and gamma ray attenuation logs - from local wells can be used to calibrate rock physics models with independent information and to improve the estimates of gas hydrate saturations based on the reprocessed seismic data. Even with such calibrations, there will always be differences between estimated gas hydrate saturations determined independently from resistivity logs and reprocessed seismic data, in part due to the different scales of measurement and resolution of the geophysical techniques (Dai et al., Part II, 2008).

A fourth key effort was the development of a new device to measure the physical properties of pressure cores soon after retrieval. Pressure coring - the process of obtaining a sediment core in a specially designed chamber capable of maintaining in situ hydrostatic pressure-had been successfully conducted in hydratebearing sediment as far back as Ocean Drilling Program (ODP) Leg 164 (Dickens et al., 1997, 2000). Until ODP Leg 204, which drilled a marine gas hydrate province on the Oregon margin in 2002 (Tréhu et al., 2003), the most meaningful analyses that could be conducted on pressure cores from gas hydrate provinces were degassing experiments in which the volume of gas derived during depressurization was used to estimate the likely concentration of gas hydrate in situ. During ODP Leg 204, pressure cores were transferred at pressure to a device that could measure P-wave velocity and gamma ray attenuation through the core liner (Tréhu et al., 2003). The JIP recognized the need to collect even more types of physical data on cores maintained at in situ pressure using sensors in direct contact within the sediment. To this end, Georgia Tech researchers constructed a new device called the integrated pressure testing chamber (IPTC), described in detail by Yun et al. (2006b). During the 2005 drilling expedition, the IPTC, shown in Fig. 3, received full-length (1-m long) pressure cores maintained at in situ hydrostatic pressure and measured P-wave, S-wave, electrical conductivity, and undrained shear strength on the sediments through small holes drilled in the core liner.

\section{Selection of JIP Phase I drilling sites}

During the decade starting in 1995, the Integrated Ocean Drilling Program (IODP) and its predecessor, the Ocean Drilling Program (ODP) conducted dedicated ocean drilling in marine gas hydrates provinces on the U.S. Atlantic margin (ODP Leg 164; Paull et al., 1996), the Oregon margin (ODP Leg 204; Tréhu et al., 2003), and the northern Cascadia margin (IODP Expedition 311; Riedel et al., 2005). These projects provided unprecedented access to gas hydrate samples, insights about the concentration and distribution of gas hydrates in marine settings, and understanding of the myriad physical, chemical, and biological processes that control the dynamics of marine gas hydrate reservoirs (e.g., Trehu et al., 2006). The ODP/IODP efforts focused on fundamental scientific processes in gas hydrate provinces, but conducted no systematic studies of geohazards. Furthermore, Gulf of Mexico drilling was notably absent from the ODP/IODP projects, despite some site survey research to evaluate potential gas hydrate targets (Ruppel et al., 2005) in that area.

In 2002, the JIP began evaluating northern Gulf of Mexico drilling sites for gas hydrate-related geohazards objectives. Key considerations in site evaluation included the potential for encountering hydrate-bearing sediment, the availability of baseline seismic data, and logistical issues such as the JIP members' access to a specific lease block. Sites at which seafloor hydrate had been detected either by academic researchers (e.g., Brooks et al., 1984; MacDonald et al., 1994; Sassen and MacDonald, 1997) or companies participating in the JIP were deemed worthy of initial consideration. Subsequently, many of these sites were discarded since seafloor hydrate occurrences were inferred to be unreliable
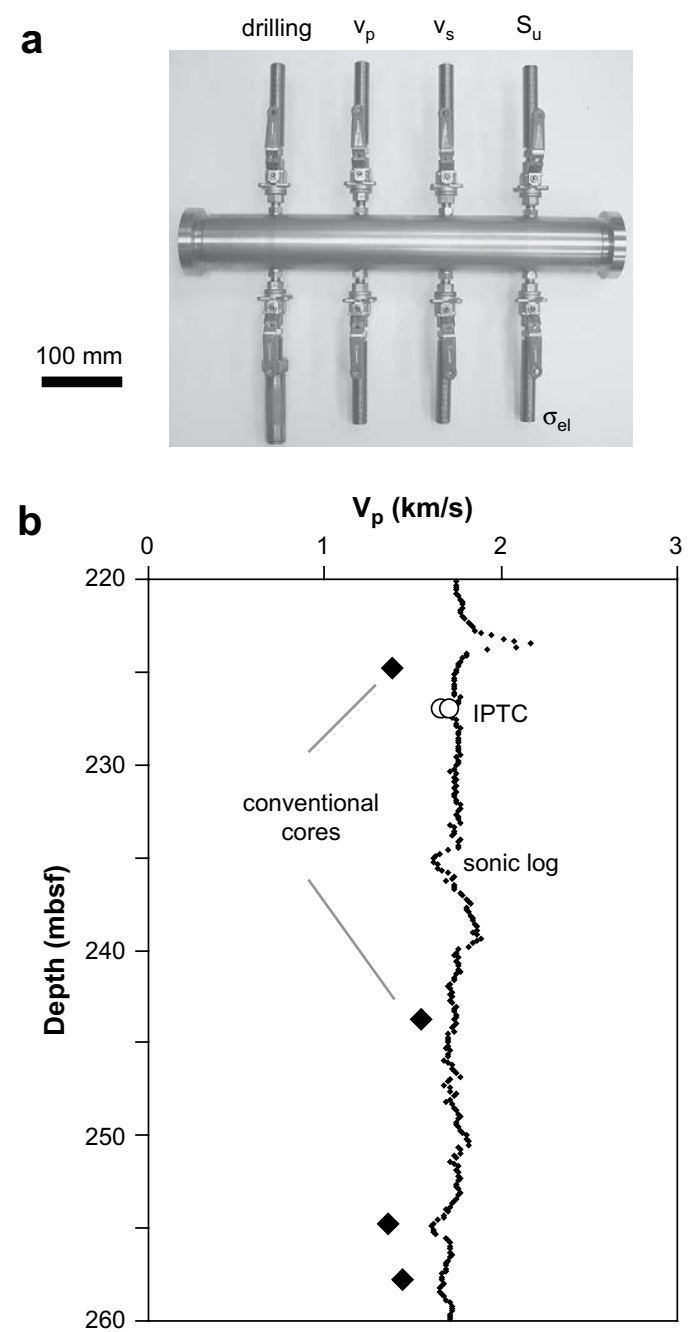

Fig. 3. (a) The Integrated Pressure Testing Chamber (IPTC) designed by Georgia Tech for measuring the physical properties of pressure cores never subjected to release of in situ hydrostatic pressure. Full details are given by Yun et al. (2006b). The pressure core enters through a ball valve at the left side, and holes are drilled through the core liner. Those holes are then successively advanced for measurement of P-wave velocity $\left(v_{\mathrm{p}}\right)$, S-wave velocity $\left(v_{\mathrm{s}}\right)$, and electrical conductivity $\left(\sigma_{\mathrm{el}}\right)$ and undrained shear strength $\left(S_{\mathrm{u}}\right)$ at the discrete ports using sensors in direct contact with the sediment. (b) P-wave velocity sonic log from a selected depth interval at KC151\#2 is shown as dots. Filled symbols denote laboratory results on conventional cores from KC151\#3 tested at atmospheric pressure, and the open symbol shows the result for a pressure core from the same hole and tested with the IPTC.

indicators of the presence of hydrate-bearing sediment deeper in the sedimentary section. Sites characterized by pressure-temperature conditions that placed them so close to the phase boundary for the stability of methane hydrate (e.g., those at $\sim 500$ to $700 \mathrm{~m}$ water depth) that only a thin zone of gas hydrate might be present were likewise discarded early in the process. Five lease blocks were given strong consideration and evaluated through reprocessing of 3-D seismic data at $4 \mathrm{~ms}$ (Dai et al., Part I, 2008): Atwater Valley 14 (AT14), Keathley Canyon (KC) 195/151, Mississippi Canyon 802, Alaminos Canyon 856, and Green Canyon 184-185.

Identification of seismic reflections that could be linked to the presence of gas hydrates played a critical role in narrowing the list of potential sites. The site selection team specifically focused on locations with bottom simulating reflections (BSR), negative impedance contrast reflections that roughly parallel the seafloor, cut across stratigraphy, and are inferred to mark the phase transition between hydrate-bearing sediment above and free gas below. 
Classic BSRs have only rarely been recognized in the northern Gulf of Mexico (e.g., Cassassuce et al., 2004; Cooper and Hart, 2003; Hutchinson et al., 2008a; McConnell and Kendall, 2002). Increasingly, even seismic features having just some of the characteristics of classic BSRs are being evaluated as potential indicators of gas hydrate and/or free gas. In the northern Gulf of Mexico, these include seismic reflections with negative impedance contrast but located in the shallow subseafloor sediments beneath seeps (e.g., Wood et al., 2008); discontinuous negative impedance reflections, or aligned terminations of such reflections, at approximately the depth of the predicted hydrate-gas phase transition but confined to the boundaries between stratigraphic units (McConnell and Kendall, 2002; Snyder et al., 2004); and positive impedance contrast features within the hydrate stability zone and possibly indicative of water-saturated sediments overlying sediments containing some gas hydrate (e.g., McConnell, 2000).

Based on preliminary scientific assessments and the advice of researchers and the JIP members, the specific areas targeted for 2005 logging and coring were narrowed to KC lease block 151 (adjacent to lease block 195) and AT13 and 14. The 3-D seismic data that had been previously reprocessed at $4 \mathrm{~ms}$ were then reprocessed at full $2 \mathrm{~ms}$ resolution to provide highly detailed information about the shallow subsurface at these sites (Snyder et al., 2004). Fig. 4 shows the sites within a regional framework, while Fig. 5 provides more detailed information about the morphology, seafloor and subseafloor features, site survey data, and drilling targets at the sites. Both areas lie in $\sim 1300 \mathrm{~m}$ of water within the minibasin province of the northern Gulf of Mexico, a stratigraphically complex area of salt-withdrawal minibasins flanked by salt-cored ridges (e.g., Peel et al., 1995). Silt-and clay-rich sediments dominate at both sites and indeed throughout much of the northern Gulf of Mexico, meaning that hydrate-bearing sediment-related geohazards data acquired at the selected drill sites could be broadly applicable across a large region and even in other marine areas characterized by fine-grained sediments. Both of the selected drill sites also have seafloor features interpreted as possible gas hydrate mounds in preliminary analyses (e.g., Dai et al., Part I, 2008; Hart et al., 2008). Such features are far more prominent at AT13/14,

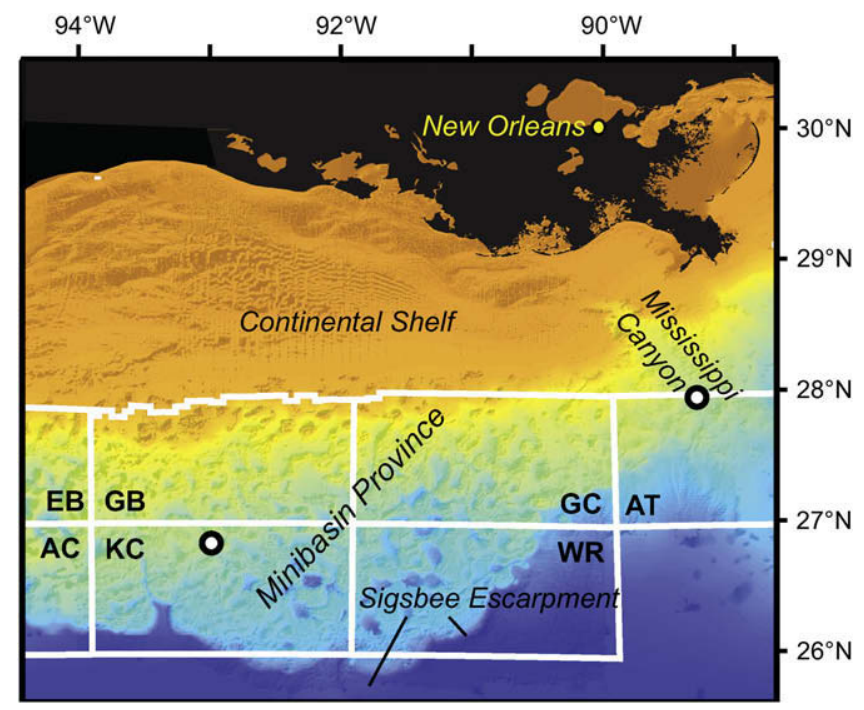

Fig. 4. Location map for the northern Gulf of Mexico showing bathymetric variations superposed on shaded geomorphologic map. The JIP drill sites in KC (Keathley Canyon) lease block 151 and the AT (Atwater Valley) blocks 13 and 14 are denoted by the white circles. Other deepwater protraction areas are East Breaks (EB), Alaminos Canyon (AC), Garden Banks (GB), and Walker Ridge (WR). Both JIP sites are at $\sim 1300 \mathrm{~m}$ of water. The minibasin province is defined by the pockmarked morphology produced by alternating salt-cored ridges and salt-withdrawal minibasins north of the Sigsbee Escarpment. which also has carbonate hardgrounds, chemosynthetic communities, and other indicators of rapid fluid flux and possible sediment fluidization. Although the AT site lacks a BSR, an anomalous, negative impedance seismic event rises close to the seafloor beneath Mound $\mathrm{F}$ and occurs at greater depths away from the mounds (Fig. 6). Local perturbation of the BGHS due to rapid upward migration of relatively warm fluids (Wood et al., 2008) might produce such an upwarped BSR-like feature. In contrast, KC151 has a clear BSR (Fig. 6) starting at $\sim 250$ below seafloor (mbsf) on the west side of the salt-cored ridge (Hutchinson et al., 2008a) that dominates the local bathymetry. The BSR dips westward, eventually reaching $\sim 440$ mbsf (Hutchinson et al., 2008a), but lies at $\sim 392 \mathrm{mbsf}$ (based on logging results of Lee and Collett, 2008) at the site drilled at KC151.

These first-order differences between the two sites suggest that they provide contrasting settings for gas hydrate occurrences, settings that are likely to be common throughout the marine environment (e.g., Roberts and Carney, 1997; Trehu et al., 2006). At $\mathrm{KC} 151$, the dynamics of fluid migration are interpreted to be characterized by slow advective flux of fluids and/or free gas, resulting in the development of a BSR (e.g., Hyndman and Davis, 1992; Xu and Ruppel, 1999) and the possible formation of gas hydrate over a thick zone within the sedimentary section. In contrast, the fluid system at AT13/14 is leaky, with focused zones of enhanced fluid flow coincident with seafloor gas hydrate mounds (e.g., Hart et al., 2008) and subseafloor seismically transparent zones, gas chimneys, and an upwarped BGHS (e.g., Wood et al., 2008).

To choose specific locations for drilling/coring and downhole logging within these two sites, advanced seismic attribute and inversion analyses were conducted on existing industry-grade 3D seismic volumes (Xu et al., 2004; Dai et al., Part I, 2008). Additional site surveys carried out at KC151 and AT13/14 during cruises in 2003 and 2004 are summarized in Table 2 and included acquisition of high-resolution multichannel and deeptow seismic (Hutchinson et al., 2008a, 2008; Wood et al., 2008), heat flow (Coffin et al., 2006; Hutchinson et al., 2008a), piston coring (Coffin et al., 2008; Pohlman et al., 2008), and seafloor electromagnetic data (Ellis et al., 2008) and photographic images (Hart et al., 2008) at one or both of the sites. The site survey seismic data were complementary to the existing 3D volumes and were acquired specifically to provide high resolution in the part of the sedimentary section within a few tens to hundreds of meters of the seafloor. The other site survey data sets constrained the geology, morphology, concentration of gas hydrate, pore water geochemical anomalies, methane flux, thermal gradients, and gas compositions at and near the seafloor, information that can sometimes prove useful in interpreting largerscale gas hydrate reservoir dynamics.

\section{JIP Phase I drilling, coring, and logging expedition overview}

The drilling expedition was conducted from the semi-submersible Uncle John between 17 April and 22 May 2005. Complete operational details and selected initial scientific results are provided by Claypool (2006) and Hippe et al. (2006). The Claypool (2006) report includes an operational summary and dedicated descriptions of well logging, pressure coring and X-ray imaging, and pore water geochemical analyses (e.g., iodide, bromide, barium) not available elsewhere. Although the individual components of the cruise report were produced by specific authors, we refer to this unpublished, yet widely available, report only as Claypool (2006) throughout this volume of scientific results papers. The references for specific data sets are given in Table 2 .

Table 3 summarizes information about the boreholes drilled during the JIP expedition. Logging while drilling (LWD) data were 
a

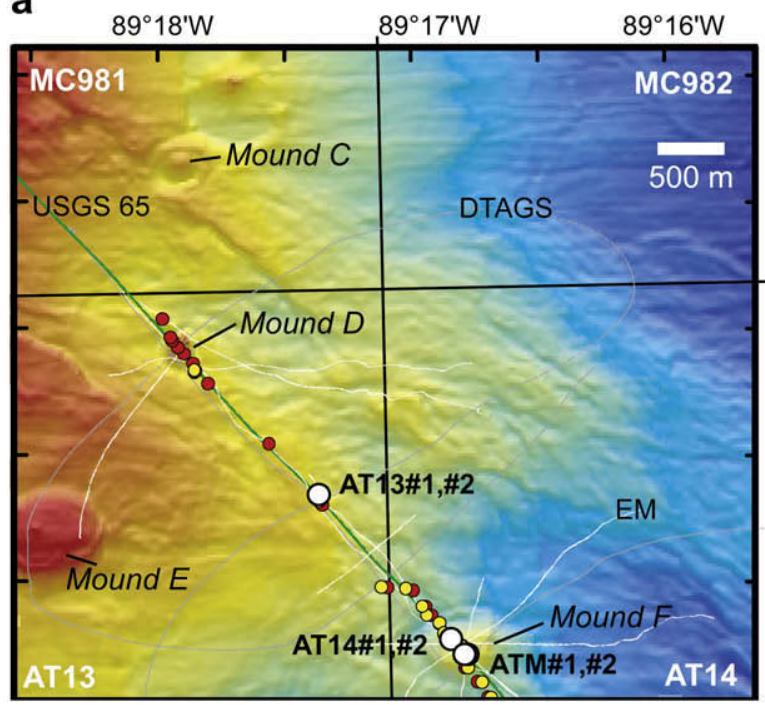

b

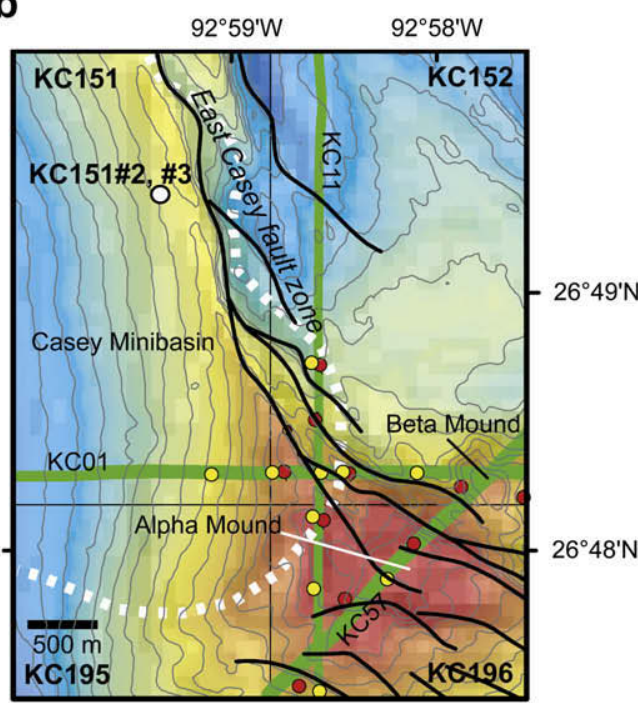

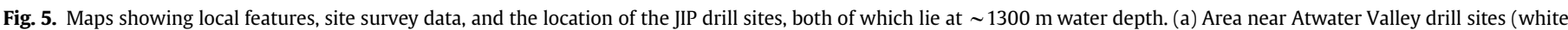

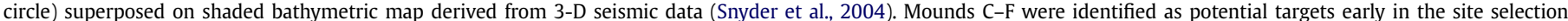

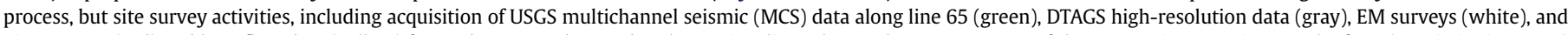

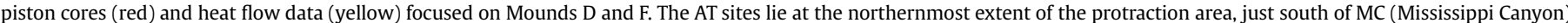

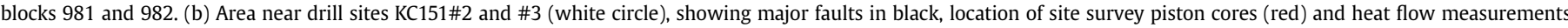

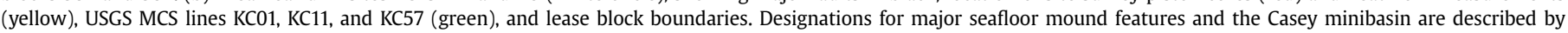

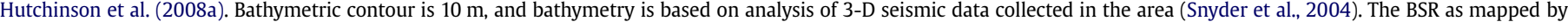
Hutchinson et al. (2008a) is recognized from high-resolution multichannel seismic data within the area north and east of the white dashed curve.

acquired in two dedicated holes at AT13/14 (AT13\#1 and AT14\#1) and one hole at KC151 (KC151\#2). AT13\#2, mound sites ATM\#1 and ATM\#2, and KC151\#3 were holes drilled for coring and wireline logging. AT13\#1 and AT13\#2 were designated as reference holes to provide background information about the sedimentary section away from the mud mounds, while AT14\#1 was drilled in the flank of Mound F, where the seismic data implied that upward migrating fluid had significantly upwarped the BSR-like seismic reflection. $\mathrm{KC} 151 \# 2$, the dedicated LWD site at KC151, was located $\sim 10 \mathrm{~m}$ from the coring hole KC151\#3, which was eventually used for wireline logging and vertical seismic profiling (VSP) as well. The KC151 holes provided access to a predominantly fine-grained sedimentary section that includes a BSR. Note that KC151\#1 is the designation given to a hole whose location was sited pre-cruise but that was never attempted.

Financial constraints, drilling platform availability, oceanographic conditions (e.g., strong loop currents at the Atwater Valley sites), and other factors affected the duration, timing, and success of the JIP expedition. In contrast to ODP expeditions, the DOE-JIP coring was not continuous, focusing instead on recovering cores in intervals of particular interest, as generalized in Table 3. Nearly all the scientific objectives of the expedition were achieved, including penetration of the BSR at KC151 and the BSR-like feature on the flank of Mound F at AT14. Holes AT13\#1 and AT14\#1 produced high-quality LWD data sets to depths of $\sim 247 \mathrm{mbsf}$ and $\sim 287$ mbsf, respectively. These depths were short of the pre-cruise target depths, but more than sufficient to provide information about the formation and to penetrate a BSR-like reflection at $\sim 180$ mbsf in AT14\#1. At AT13\#2, the deepest core was retrieved from $158 \mathrm{mbsf}$ before the hole was lengthened to $200 \mathrm{mbsf}$ to commence wireline logging. Collapse thwarted attempts to complete wireline logging in that hole. Post-cruise analysis of LWD logs showed that the problems with the AT\#13 and AT\#14 holes were caused not by gas hydrates, but rather by the development of
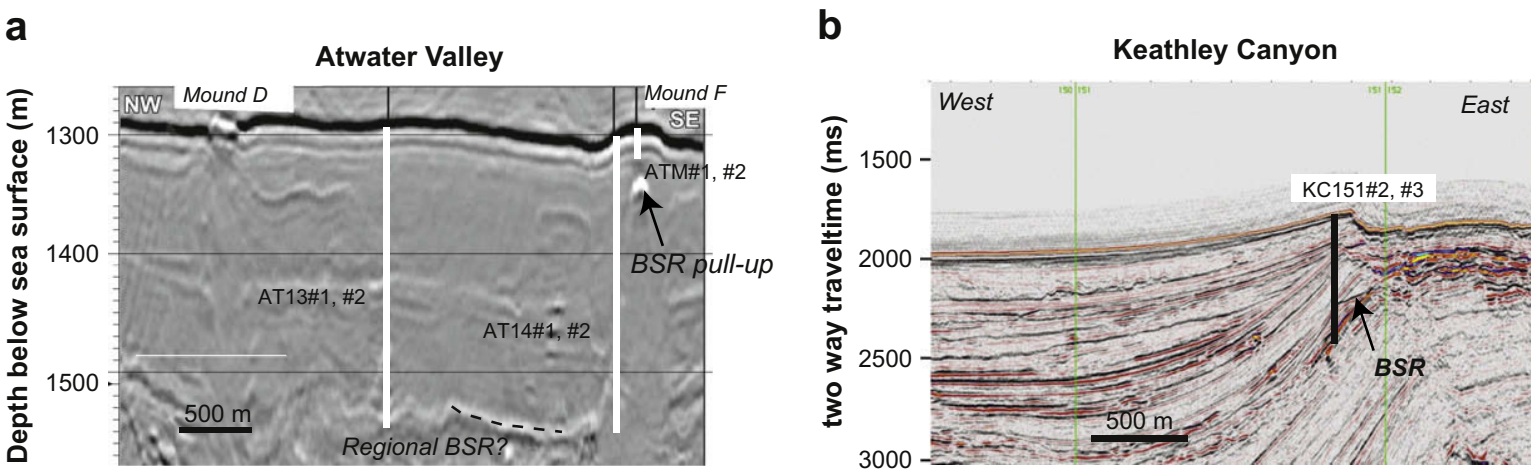

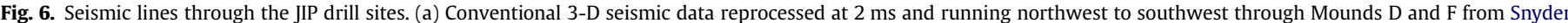

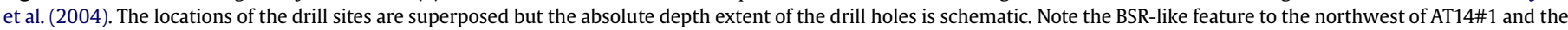

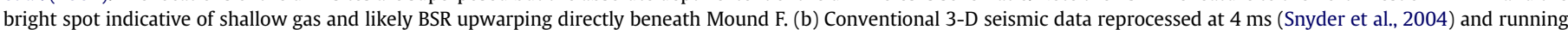

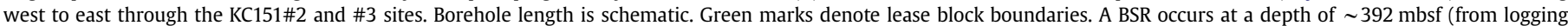
analyses) and intersects the borehole. 
Table 2

Resources that describe site survey studies and results from the 2005 JIP expedition

\begin{tabular}{lll}
\hline & Atwater valley 13/14 & Keathley canyon 151 \\
\hline $\begin{array}{l}\text { Site survey } \\
\text { Seismic } \\
\text { 3-D }\end{array}$ & Snyder et al. (2004) & Snyder et al. (2004) \\
& $\begin{array}{l}\text { Dai et al. } \\
\text { (Part I, 2008) }\end{array}$ & $\begin{array}{l}\text { Dai et al. } \\
\text { (Part I, 2008) }\end{array}$ \\
\multicolumn{1}{c}{ MCS } & Hart et al. (2005) & Hart et al. (2005) \\
& Hutchinson and Hart (2004) & Hutchinson and Hart (2004) \\
& & Hutchinson et al. (2008a) \\
& & Hutchinson et al. \\
(2008)
\end{tabular}

The cruise report (Claypool, 2006) discusses many of the preliminary results of the coring/logging expedition, but more recent work listed here supersedes the report in most cases.

packoffs, drilling-induced fractures, and enlarged hole conditions (Birchwood et al., 2007).

KC151\#2 was initially drilled to $\sim 460$ mbsf, well below the estimated BSR depth (392 mbsf from Lee and Collett, 2008). A highquality LWD data set was obtained for this hole, which was eventually lost and allowed to collapse due to flow verified by the ROV. The flow was eventually stopped with drilling mud prior to hole abandonment. At adjacent hole KC151\#3, the deepest core was acquired at $\sim 390$ mbsf, which is the approximate depth of the BSR. The hole began to flow as it was being prepared for wireline logging after the completion of coring. The flow was brought under control, and wireline logging and a VSP study were completed over the interval from $\sim 50 \mathrm{~m}$ to $\sim 60 \mathrm{~m}$ above the BSR up to $\sim 123 \mathrm{mbsf}$ and $\sim 94$ mbsf, respectively.

The logging report produced by Collett within the JIP cruise report (Claypool, 2006) provides exhaustive information about the JIP LWD and wireline logging programs, including the goals, the tools deployed, the problems encountered, and the preliminary findings. Difficult hole conditions prevented the completion of the full suite of wireline logs originally planned for the expedition, but the LWD data in particular provide exhaustive information that has been used in a wide range of studies about borehole stress state and temperature, gas hydrate saturations, and in situ physical properties (Birchwood et al., 2007; Cook et al., 2008; Dai et al. Part I, 2008; Lee and Collett, 2008; Yun et al., 2006b).

The JIP drilling expedition used a variety of coring devices. In the shallow section, cores were acquired using the Fugro Hydraulic
Piston Corer (FHPC), which can be fit with either 4.6-m long or 7-m long core barrels. The FHPC is designed to cause relatively minimal disturbance of the formation and maintains gas voids intact. Core retrieval rates with the FHPC were 95\% (Claypool, 2006). In the more consolidated sediments that characterized the deeper part of the section at KC151, a hammer corer (Fugro Corer FC) that can accommodate either 3-m long or 3.6-m long core barrels was used, producing substantially greater disruption of the recovered sediment, lower core recovery, and destruction of gas voids. Two pressure coring systems were also deployed during the expedition: The HYACE Rotary Corer (HRC) and the Fugro Pressure Corer (FPC) both have $1-\mathrm{m}$ long core barrels and are designed to maintain sediments at in situ hydrostatic pressure. Only 5 of the 18 pressure cores attempted during the expedition successfully recovered sediments at pressure.

Once aboard ship, conventional cores acquired by the FHPC and FC were scanned with an infrared (IR) camera to identify cold spots associated with dissociating gas hydrate and sub-sectioned for analyses of pore waters (e.g., Kastner et al., 2008) and gases (Lorenson et al., 2008). The remaining core whole round sections were passed through a multisensor track that automatically measured numerous physical properties through the acrylic core liner. Core material was also retained for physical properties analyses both aboard ship and after the cruise (Hippe et al., 2006; Winters et al., 2008; Yun et al., 2006a), for permeability and consolidation tests (Dugan, 2008), and for later laboratory experiments on the mechanical and electromagnetic properties of natural sediments with and without synthetic hydrates (Lee et al., 2008). Some recovered pressure core material was subjected to X-ray analysis aboard ship and degassing experiments (Claypool, 2006). One pressure core from KC151 was analyzed using the IPTC (Yun et al., 2006b).

\section{Gas hydrate occurrences}

The expedition did not recover visible gas hydrate during any of the coring operations, nor was gas hydrate directly imaged in pressure cores that were subjected to X-ray analyses (Claypool, 2006). While the failure to recover gas hydrate may indicate that none was encountered at the drill sites, it is more likely that various factors frustrated efforts to recover hydrate. First, the bulk of the sediments at the drill sites are fine-grained, meaning that hydrate concentrations in many intervals (e.g., other than fractures or sandrich sublayers) could have been small or the hydrate highly disseminated. Second, the combination of relatively low saturations in most intervals, the long time for core retrieval, and the warm seawater that had to be traversed by both pressure cores and conventional cores would have increased the likelihood that any hydrate present in situ had dissociated by the time the core was analyzed on the ship. Related issues associated with lack of direct recovery of gas hydrate are discussed by Lee and Collett (2008) and in less detail by Claypool (2006).

Several indirect indicators and quantitative analyses imply that gas hydrate was probably encountered during the drilling, particularly in fractures and in relatively coarse-grained layers within the fine-grained silts and muds between $220 \mathrm{mbsf}$ and $330 \mathrm{mbsf}$ at KC151. Freshening of pore waters relative to background salinities was detected at depths greater than 200 mbsf at this site by Kastner et al. (2008), an observation consistent with dissociation of in situ hydrate (e.g., Hesse and Harrison, 1981). Elevated resistivity values and some features in the sonic logs (Lee and Collett, 2008) also suggest the presence of gas hydrate locally occupying up to $20 \%$ of pore space at some levels within the $220-330$ mbsf interval. The interval between $220 \mathrm{mbsf}$ and $258 \mathrm{mbsf}$ particularly had geophysical characteristics (elevated resistivity and seismic velocity) indicative of gas hydrate. Resistivity at bit (RAB) imagery and 
Table 3

Summary of logging and coring sites for the 2005 JIP expedition

\begin{tabular}{|c|c|c|c|c|c|c|}
\hline Borehole & Location/objective & Location & $\begin{array}{l}\text { Water depth } \\
(\mathrm{m})^{\mathrm{a}}\end{array}$ & Sampled intervals & Total depth (m) & Comments \\
\hline AT13\#1 & $\begin{array}{l}\text { LWD hole; } \\
\text { Reference section away } \\
\text { from seafloor mounds }\end{array}$ & $89.2893^{\circ} \mathrm{W}$ & 1290.5 & $\begin{array}{l}\text { Push core } \\
\text { at seafloor, LWD entire depth }\end{array}$ & 246.3 & $\begin{array}{l}\text { LWD data } \\
\text { suite obtained. }\end{array}$ \\
\hline AT13\#2 & $\begin{array}{l}\text { Coring and wireline } \\
\text { logging hole; Same } \\
\text { location and objective } \\
\text { as AT13\#1 }\end{array}$ & $89.2893^{\circ} \mathrm{W}$ & 1291.1 & Coring: $0-48 \mathrm{~m}$ and $118-158 \mathrm{~m}$ & 199.9 & $\begin{array}{l}\text { Stopped short } \\
\text { of pre-cruise target } \\
\text { depth of } \sim 315 \text { mbsf; } \\
\text { no wireline logging } \\
\text { completed due to borehole conditions. }\end{array}$ \\
\hline AT14\#1 & $\begin{array}{l}\text { LWD hole: } \\
\text { Flank of Mound F where } \\
\text { BSR-like feature } \\
\text { has started to shoal }\end{array}$ & $\begin{array}{l}27.9376^{\circ} \mathrm{N} \\
89.2806^{\circ} \mathrm{W}\end{array}$ & 1300.2 & $\begin{array}{l}\text { Push core } \\
\text { at seafloor, LWD entire depth }\end{array}$ & 286.6 & $\begin{array}{l}\text { LWD suite } \\
\text { obtained and penetrated BSR-like feature } \\
\text { at } \sim 180 \text { mbsf. }\end{array}$ \\
\hline ATM\#1 & Crest of Mound F & $\begin{array}{l}27.9366^{\circ} \mathrm{N} \\
89.2795^{\circ} \mathrm{W}\end{array}$ & 1296.0 & Coring: $0-27 \mathrm{~m}$ & 26.8 & \\
\hline ATM\#2 & Crest of Mound F & $\begin{array}{l}27.9366^{\circ} \mathrm{N} \\
89.2797^{\circ} \mathrm{W}\end{array}$ & 1295.4 & Coring: 0-29 m & 29.0 & \\
\hline KC151\#2 & $\begin{array}{l}\text { LWD hole: } \\
\text { Keathley Canyon, on east } \\
\text { flank of Casey } \\
\text { Minibasin, with BSR at } \\
\sim 392 \text { mbsf (based on logs) }\end{array}$ & $92.9865^{\circ} \mathrm{W}$ & 1321.8 & $\begin{array}{l}\text { Push core } \\
\text { at seafloor, LWD entire depth }\end{array}$ & 459.8 & $\begin{array}{l}\text { LWD data } \\
\text { suite obtained; hole } \\
\text { quality slightly deteriorated } \\
\text { in uppermost } 110 \mathrm{~m} .\end{array}$ \\
\hline KC151\#3 & $\begin{array}{l}\text { Coring, VSP, }{ }^{\mathrm{b}} \text { and wireline } \\
\text { logging hole: } 10 \mathrm{~m} \text { from KC151\#2 }\end{array}$ & $\begin{array}{l}26.823^{\circ} \mathrm{N} \\
92.9867^{\circ} \mathrm{W} \\
\text { VSP: } 94.1-334 \mathrm{~m}\end{array}$ & 1322.5 & $\begin{array}{l}\text { Coring: } 0-45 \mathrm{~m} ; 100-103 \mathrm{~m} \text {; } \\
210-390 \mathrm{~m} \\
\text { (with some gaps) } \\
\text { Wireline logging: } 123-341 \mathrm{~m}\end{array}$ & 441.4 & $\begin{array}{l}\text { Stopped short } \\
\text { of pre-cruise target depth of } \sim 457 \mathrm{mbsf} \text {; } \\
\text { flow problem developed after coring and } \\
\text { before wireline logging, but logging and } \\
\text { VSP were completed to } \sim 50 \text { to } 60 \mathrm{~m} \\
\text { above nominal BSR. }\end{array}$ \\
\hline
\end{tabular}

All depths, locations, and operational notes reported here supersede those reported in the operational summary of Claypool (2006).

a Depths for LWD holes from Collett report in Claypool (2006). Depths for holes intended for coring and wireline logging are taken from the core curation databases.

b Vertical seismic profiling.

borehole breakout data analyzed by Cook et al. (2008) point to fracture networks as the likely locus of concentrated gas hydrate. Their independent analysis of log data yields inferences of gas hydrate in beds at $109 \mathrm{mbsf}, 231-235 \mathrm{mbsf}$, and $306 \mathrm{mbsf}$ and in fractures primarily in the intervals of $220-250 \mathrm{mbsf}$ and 265300 mbsf, with greater than $20 \%$ hydrate saturation in a $49-\mathrm{m}$ thick interval within the fractured sediments. Nearly all the IR imagery acquired on recovered cores during the drilling expedition failed to distinguish between gas expansion features and cool spots produced during the endothermic dissociation of gas hydrate (e.g., Weinberger et al., 2005). At 253.4 mbsf in Hole KC151\#3, the IR imagery clearly revealed a cold spot with all of the characteristics of dissociating methane hydrate though (Claypool, 2006). Degassing of several pressure cores within the $236-383$ mbsf interval produced enough methane to support the inference of in situ gas hydrate concentrations of $6 \%$ and $1.5 \%$ of pore space, respectively (Claypool, 2006), although some caution is required in interpreting the results of these experiments. Kastner et al. (2008) independently estimated hydrate saturations at $1-12 \%$ of pore volume using pore water chloride anomalies. Overall, we interpret the data to indicate that gas hydrate was present in situ in several intervals at KC151. The disparities in the estimated concentrations can be explained by the different detection techniques and their resolution.

For the AT13/14 reference sites and the sites at Mound F, assessing the possibility that drilling encountered gas hydrate is more difficult. At reference sites, the best direct evidence for the occurrence of gas hydrate was thin zones of elevated resistivity detected in the interval of 125-128 mbsf at AT13\#1 (Claypool, 2006). Pore water freshening also occurred within this interval (Kastner et al., 2008). Resistivity logs at AT14\#1 provide some indication of shallow gas hydrate (less than 65 mbsf) at estimated saturations of $10-20 \%$ of pore space, but an elevated resistivity interval $\sim 40$-m thick starting at 180 mbsf may be more likely reflect free gas beneath a BSR-like feature at $180 \mathrm{mbsf}$ (Claypool, 2006).

The Atwater Valley mound sites ATM\#1 and ATM\#2 were only cored and not logged. Inferences about gas hydrate occurrences rely on circumstantial evidence. IR imagery could not be unequivocally interpreted as being consistent with gas hydrate dissociation instead of gas expansion. Seafloor morphologic data, EM data, and interpretations of seismic data sets with overlapping resolution suggest that gas hydrate might be present at some depths between the seafloor and $\sim 50$ mbsf at the Atwater Valley mound sites (Dai et al., Part II, 2008; Ellis et al., 2008; Hart et al., 2008; Wood et al., 2008). Kastner et al. (2008) interprets 4 ppt of pore water freshening (relative to a maximum of 55.5 ppt salinity) at ATM1 to indicate in situ gas hydrate saturation of $4-5 \%$ of pore space. Degassing of a pressure core recovered from $\sim 17$ mbsf produced gas consistent with $1-5 \%$ of pore space being filled by gas hydrate in situ (Claypool, 2006). Qualitative evidence for gas hydrate included gas voids, cooler spots imaged by the IR instrumentation, and moussey-textured sediments produced by the destruction of soil texture during gas hydrate dissociation.

\section{Major findings and contributions}

The JIP drilling expedition and related studies made important contributions to the understanding of fine-grained hydrate-bearing sediment in marine settings and associated geohazards. As the first drilling program designed to study marine gas hydrates in a major deepwater petroleum province, the JIP expedition demonstrated that such drilling could be conducted safely in this environment. As expected based on the lessons of other marine gas 
hydrate drilling projects (e.g., ODP Legs 164 and 204, IODP Expedition 311), the JIP expedition also safely penetrated a BSR and presumed gas hydrate intervals without disruption of the seafloor or drilling instrumentation as a result of dissociation processes. Compared to research drilling conducted by ODP/IODP, the JIP drilling expedition implemented only a few additional measures, such as extensive use of a ROV for monitoring the conditions near the hole on the seafloor. Such measures are already widely used by energy companies and thus do not represent a major impediment to future exploration and production activities in deepwater marine settings in which gas hydrate occurs in the shallow subseafloor. The hole conditions encountered at KC151 (flow problems) and the AT13/14 reference sites (borehole collapse) are not believed to be connected to the possible presence of gas hydrates at these sites. Similar shallow drilling issues are routinely encountered and successfully managed in deepwater Gulf of Mexico operations.

Consistent with the findings of earlier studies of marine gas hydrates (Dillon et al., 1997; Ginsburg et al., 2000; Kraemer et al., 2000; Nimblett and Ruppel, 2003; Riedel et al., 2005; Sassen et al., 2001; Trehu et al., 2006; Weinberger and Brown, 2006; Wood and Ruppel, 2000), the JIP coring and logging data imply that local permeability plays the dominant role in controlling the distribution and concentration of gas hydrate in fine-grained sediments having access to sufficient gas charge. At KC151, the enhanced local permeability within the inferred hydrate-bearing interval is in the form of both sand-rich clay layers and fractures (Cook et al., 2008; Lee and Collett, 2008), and logging data are consistent with hydrate concentrations as high as $20 \%$ at some places within the 220 $330 \mathrm{mbsf}$ interval. This value is comparable to hydrate saturations inferred for some enhanced permeability layers (e.g., Ginsburg et al., 2000; Kraemer et al., 2000) within the thick, fine-grained, clay-dominated sedimentary section on the Blake Ridge (Collett and Ladd, 2000).

Comparison of data from the sites drilled at Mound F in AT14 (ATM\#1 and ATM\#2) to logging data and a surface push core obtained at AT14\#1, less than $100 \mathrm{~m}$ away, shows the effects of the enhanced fluid flow beneath the mound to be very limited in spatial extent (Claypool, 2006). This finding confirms the results of earlier studies by Paull et al. (2005) and Ruppel et al. (2005), who highlighted the importance of focused flow in modifying conditions (e.g., temperature, pore water salinity) near conduits feeding seeps and mounds in the deepwater Gulf of Mexico and provides important constraints on the lateral extent of the subseafloor perturbation associated with Mound F. The results obtained at the Atwater mounds also argue against using seafloor gas hydrate mounds or other seafloor features associated with fluid flow to infer either high concentrations of gas hydrate at depth or accumulations of gas hydrate at depth over areas much larger than the seafloor manifestation of enhanced fluid migration. The decision to place relatively little emphasis on seafloor occurrences of gas hydrate as a criterion for JIP site selection was therefore validated.

Post-cruise comparison of the LWD data and the wellbore stability model for fine-grained hydrate-bearing sediment generally confirmed pre-cruise predictions about the mechanical behavior of the boreholes at the AT13/14 and KC151 sites (Birchwood et al., 2007). At both sites, borehole temperatures were significantly colder than predicted by the model though. For AT13/14, this disparity could be explained by loop currents that cooled the drill pipe and drilling fluid more than expected. Overall, the JIP expedition proved that some hazards associated with operations in areas characterized by shallow gas hydrates and/or free gas can be anticipated through borehole stability modeling and avoided by using such models to guide decisions on drilling fluid circulation rates (Birchwood et al., 2007).
The JIP drilling also acquired data that validated the approach of inferring gas hydrate and free gas distribution and estimating gas hydrate concentrations through reprocessing of existing industrystandard 3-D seismic data that had originally been acquired for delineation of deep conventional oil and gas targets (Xu et al., 2004; Dai et al., Parts I and II, 2008). Borehole conditions more conducive to completion of the logging program that had been planned prior to the cruise would certainly have provided a more complete test of the seismic data analysis approach and opportunities to more closely calibrate the rock physics models necessary for estimation of gas hydrate saturations. Nonetheless, comparison of the pre-drill hydrate saturation estimates made from processing of the 3-D seismic data in the deep section at KC151 to analyses of downhole logs (Dai et al., Part II, 2008) demonstrates the considerable promise of detecting gas hydrates with conventional seismic data. For the upper section at KC151, the disparity between gas hydrate saturations estimated before the cruise from analysis of the seismic data and after the cruise based on the logging results may reflect the need for better rock physics constraints for very high porosity, unconsolidated sediments. At the Atwater Valley mound sites, drilling probably did not penetrate deeply enough (maximum depth $\sim 30 \mathrm{mbsf}$ ) to provide a valid test for seismically-based inferences of significant hydrate concentrations just shallower than $\sim 50$ mbsf.

The JIP expedition marked the first time that seismic, electrical, and strength properties were ever recorded on sediment cores that had been retrieved and always maintained at in situ hydrostatic pressure (Yun et al., 2006b). Although the pressure core material analyzed by the IPTC device was recovered from within the inferred hydrate-bearing interval at KC151, there was no evidence of in situ hydrate in the core. Nonetheless, the IPTC data more closely matched wavespeeds determined from downhole sonic logs than did laboratory analyses on conventional (non-pressure) cores, providing convincing preliminary evidence that measuring the properties of pressure cores could enhance our understanding of in situ conditions. The IPTC also provides an independent source of data for use in calibrating models that rely on small- (seismic) or large-strain mechanical parameters for predicting the properties or behavior of sediments with or without gas hydrate.

\section{Future research}

With the completion of the phase of JIP research focused on gas hydrate-related geohazards in fine-grained marine sediments, the project is next turning its attention to coarse-grained hydratebearing sediments (Hutchinson et al., 2008b; Jones et al., 2008). In 2009 and 2010, the JIP anticipates logging and coring at deepwater Gulf of Mexico sites chosen through the application of a petroleum systems approach (Hutchinson et al., 2008b; Jones et al., 2008). Identification of potential hydrate-bearing sections using direct evidence from existing resistivity logs (where available) or seismic indicators are the most critical components of initial site selection. Advanced seismic analysis methods (Dai et al., Part I, 2008) devised during the first phase of the JIP project for reprocessing existing 3-D data and estimating gas hydrate saturations are used to evaluate the most promising sites. Geologic constraints derived from interpreting sand deposition patterns are providing critical ancillary data for locating coarse-grained deposits (e.g., Jones et al., 2008). The site selection process is also adopting elements of a petroleum systems approach, focusing specifically on locating sand-rich units (a) within the hydrate stability zone, (b) close to a gas source; and (c) with the potential to have been charged by that gas through faults or intervening high permeability units that act as migratory pathways. In addition, the JIP is also undertaking concerted efforts to refine coring technology for use in recovering sand-dominated lithologies, to improve pressure coring capabilities, and to support 
the improvement of the IPTC (Yun et al., 2006b) and related design of a new vessel that can restore in situ effective stress on pressure core material soon after retrieval.

\section{Acknowledgments}

We thank the crew of the Uncle John and the shipboard scientific party for their dedication in completing the drilling program and associated analyses. We thank D. Hutchinson and B. Dugan for suggestions that significantly improved the paper, B. Dugan and T. Collett for clarification of cruise results and the cruise report, and D. Hutchinson and W. Wood for contributing material for figures. E.J.'s participation in this project was supported by the U.S. Department of Energy, under award DE-FC26-01NT41330. However, any opinions, findings, conclusions, or recommendations expressed herein are those of the authors and do not necessarily reflect the views of the DOE or the USGS. Any use of a trade, product, or firm names is for descriptive purposes only and does not imply endorsement by the U.S. Government.

\section{References}

Birchwood, R.A., Noeth, S., Tjengdrawira, M.A., Kisra, S.M., Elisabeth, F.L., Sayers, C. M., Singh, R., Hooyman, P.J., Plumb, R.A., Jones, E., Bloys, J.B., 11-14 November 2007. Modeling the mechanical and phase change stability of wellbores drilled in gas hydrates by the Joint Industry Participation Program (JIP) Gas Hydrates Project Phase II. In: SPE Annual Technical Conference, SPE 110796.

Brooks, J., Kennicutt II, M.C., Fay, R.R., McDonald, T.J., Sassen, R., 1984. Thermogenic gas hydrates in the Gulf of Mexico. Science 225, 409-411.

Cassassuce, F., Rector, J.W., Hoversten, M., April 2004. Study of gas hydrates in the deep-sea Gulf of Mexico from seismic data. The Leading Edge, 366-372.

Claypool, G.E. (Ed.), 2006. Gulf of Mexico Gas Hydrate Joint Industry Project (GOMJIP), 2005. The cruise of the drilling vessel Uncle John, Mobile, Alabama to Galveston, Texas, Atwater Valley Blocks 13/14 and Keathley Canyon Block 151, 17 April-22 May 2005. <http://www.netl.doe.gov/technologies/oil-gas/publications/Hydrates/reports/GOMJIPCruise05.pdf $>$.

Coffin, R.B., Gardner, J., Pohlman, J., Downer, R., Wood, W., 2006. Methane hydrate exploration, Atwater Valley, Texas-Louisiana Shelf: geophysical and geochemical profiles. US Naval Research Laboratory Technical Memorandum, NRL/ MR/6110-06-9002.

Coffin, R.B., Hamdan, L., PlummerSmith, R.J., Gardner, J., Wood, W.T., 2008. Analysis of methane and sulfate flux in methane charged sediments from the Mississippi Canyon, Gulf of Mexico. Mar. Petr. Geol. 25, 977-987.

Cook, A.E., Goldberg, D., Kleinberg, R.L., 2008. Fracture-controlled gas hydrate systems in the northern Gulf of Mexico. Mar. Petr. Geol. 25, 932-941.

Collett, T.S., Ladd, J., 2000. Detection of gas hydrate with downhole logs and assessment of gas hydrate concentrations (saturations) and gas volumes on the Blake Ridge with electrical resistivity log data. In: Paull, C.K., Matsumoto, R., Wallace, P.J., Dillion, W.P. (Eds.), Proc. ODP Sci. Results, 164, pp. 179-191.

Cooper, A.K., Hart, P.E., 2003. High-resolution seismic-reflection investigation of the northern Gulf of Mexico gas-hydrate-stability zone. Mar. Petr. Geol. 19, 1275-1293.

Dai, J., Xu, H., Snyder, F., Dutta, N., Herron, D., 2004. Detection and estimation of gas hydrates using rock physics and seismic inversion; examples from the northern deepwater Gulf of Mexico. The Leading Edge 23, 60-66.

Dai, J., Banik, N., Gillespie, D., Dutta, N., 2008. Exploration for gas hydrates in the deepwater, northern Gulf of Mexico: Part II. Model validation by drilling. Mar. Petr. Geol. 25, 830-844.

Dai, J., Snyder, F., Gillespie, D., Koesoemadinata, A., Dutta, N., 2008. Exploration for gas hydrates in the deepwater northern Gulf of Mexico: Part I. A seismic approach based on geologic model, inversion and rock physics principles. Mar. Petr. Geol. 25, 845-859.

Dickens, G.R., Paull, C.K., Wallace, P., ODP Leg 164 Scientific Party, 1997. Direct measurement of in situ methane quantities in a large gas hydrate reservoir. Nature 385, 427-428.

Dickens, G.R., Wallace, P.J., Paull, C.K., Borowski, W.S., 2000. Detection of methane gas hydrate in the pressure core sampler (PCS): volume-pressure-time relations during controlled degassing experiments. In: Paull, C.K., Matsumoto, R., Wallace, P.J., Dillon, W.P. (Eds.), Proc. ODP Sci. Results, 164, pp. 113-126. College Station, TX (Ocean Drilling Program).

Dillon, W.P., Holbrook, W.S., Drury, R.M., Gettrust, J.F., Hutchinson, D.R., Booth, J.S., Taylor, M., Judzis, A., 1997. Faulting of gas-hydrate-bearing marine sediments; contribution to permeability. Proc. Off. Tech. Conf. 29, 201-209.

Dugan, B., 2008. Fluid flow in the Keathley Canyon 151 mini-basin, Northern Gulf of Mexico. Mar. Petr. Geol. 25, 919-923.

Ellis, M., Evans, R.L., Hutchinson, D.R., Hart, P.E., Gardner, J., Hagen, R., 2008. Electromagnetic surveying of seafloor mounds in the Gulf of Mexico. Mar. Petr. Geol. 25, 960-968.
Evans, J., Fornari, D., Gilbert, L., Boyle, M., Dougherty, J., Hutchinson, D.R., 21-24 June 2004. Archive of raw bottom photographs taken during cruise P1-04-GM, Northern Gulf of Mexico. USGS Open File Report 2004-1285, <http://woodshole.er.usgs.gov/openfile/of2004-1285/>.

Evans, R.L., 2004. Cruise Report: R/V Pelican Cruise PE 04-49 Atwater Valley Electromagnetic Survey and Camera Tow. Woods Hole Oceanographic Institution Report, 19 pp., <http://woodshole.er.usgs.gov/openfile/of2004-1285/docs/P1_ 04_GM_report.pdf $>$.

Ginsburg, G., Soloviev, V., Matveeva, T., Andreeva, I., 2000. Sediment grain-size control on gas hydrate presence, Sites 994, 995, and 997. In: Paull, C.K., Matsumoto, R., Wallace, P.J., Dillon, W.P. (Eds.), Proc. ODP Sci. Results, 164, pp. 237-245. College Station, TX (Ocean Drilling Program).

Hart, P.E., Hutchinson, D.R., Gardner, J., Carney, R.S., Fornari, D., 2008. A photographic and acoustic transect across two deep-water seafloor mounds, Mississippi Canyon, northern Gulf of Mexico. Mar. Petr. Geol. 25, 969-976.

Hart, P.E., Hutchinson, D.R., Lee, M.W., 2005. High-resolution multichannle seismicreflection data acquired in the northern Gulf of Mexico, 2003. U.S. Geol. Surv. Open-File Report 2005-1411, <http://pubs.usgs.gov/of/2005/1411/>.

Hesse, R., Harrison, W.E., 1981. Gas hydrates (clathrates) causing porewater freshening and oxygen isotope fractionation in deep-water sedimentary sections of terrigenous continental margins. Earth Planet. Sci. Lett. 55, 453-462.

Hippe, F.W., Humphrey, G.D., Tjok, K-M., 2006. Geotechnical Investigation, Chevron Gulf of Mexico Gas Hydrates JIP, Blocks 13 and 14, Atwater Valley area, Block 151, Keathley Canyon Area, Gulf of Mexico, Results of Core Sample Analysis, Standard and Advanced Laboratory Testing, Report 0201-5081. Houston, TX, <http://www.netl.doe.gov/technologies/oil-gas/FutureSupply/MethaneHydrates/ rdprogram/GOM_JIP/hydrates_main.html>.

Hovland, M., Gudmestad, O.T., 2001. Potential influence of gas hydrates on seabed installations. In: Paull, C.K., Dillon, W. (Eds.), Natural Gas Hydrates; Occurrence, Distribution and Detection. American Geophysical Union Monograph 124, pp. 307-315. Washington, DC.

Hutchinson, D.R., Hart, P.E., 2004. Cruise report for G1-03-GM USGS gas hydrates cruise, R/V Gyre, 1-14 May, 2003, Northern Gulf of Mexico: US Geological Survey Open-File Report OF 03-474, 103 pp.

Hutchinson, D.R., Hart, P.E., Ruppel, C.D., Snyder, F., Dugan, B., 2008a. Seismic and thermal characterization of a Bottom Simulating Reflection in the northern Gulf of Mexico. In: Collett, T.S., Johnson, A., Knapp, C., Boswell, R. (Eds.), Natural Gas Hydrates: Energy Resources, Potential and Associated Geologic Hazards. AAPG Special Publication.

Hutchinson, D.R., Shelander, D., Dai, J., McConnell, D., Shedd, W., Frye, M., Ruppel, C., Boswell, R., Jones, E., Collett, T., Rose, K., Dugan, B., Wood, W., Latham, T., 2008b. Site selection for DOE/JIP gas hydrate drilling in the Northern Gulf of Mexico. Proceedings of the International Conference on Gas Hydrates, Vancouver, B.C. Canada, July 6-10, CD-ROM.

Hutchinson, D.R., Hart, P.E., Collett, T.S., Edwards, K.M., Twichell, D.C., Snyder, F., 2008. Geologic framework of the 2005 Keathley Canyon gas hydrate research well, northern Gulf of Mexico. Mar. Petr. Geol. 25, 906-918.

Hyndman, R.D., Davis, E.E., 1992. A mechanism for the formation of methane hydrate and seafloor bottom-simulating reflectors by vertical fluid explusion. J. Geophys. Res. 97, 7025-7041.

Jones, E., Latham, T., McConnell, D., Frye, M., Hunt, J., Shedd, W., Shelander, D. Boswell, R., Rose, K., Ruppel, C., Hutchinson, D., Collett, T., Dugan, B., Wood, W., 2008. Scientific objectives of the Gulf of Mexico gas hydrate JIP Leg II drilling, OTC 19501.

Kastner, M., Claypool, G., Robertson, G., 2008. Geochemical constraints on the origin of the pore fluids and gas hydrate distribution at Atwater Valley and Keathley Canyon, northern Gulf of Mexico. Mar. Petr. Geol. 25, 860-872.

Kraemer, L.M., Owen, R.M., Dickens, G.R., 2000. Lithology of the upper gas hydrate zone, Blake Outer Ridge: a link between diatoms, porosity, and gas hydrate. In: Paull, C.K., Matsumoto, R., Wallace, P.J., Dillon, W.P. (Eds.), Proc. ODP Sci. Results, 164, pp. 220-236. College Station, TX (Ocean Drilling Program).

Lee, J.Y., 2007, Hydrate-bearing sediments: formation and geophysical properties. Ph.D. thesis, Georgia Institute of Technology, $241 \mathrm{pp}$.

Lee, J.Y., Santamarina, J.C., Ruppel, C., 2008. Mechanical and electromagnetic properties of northern Gulf of Mexico sediments with and without THF hydrates. Mar. Petr. Geol. 25, 884-895.

Lee, M., Collett, T., 2008. Integrated analysis of well logs and seismic data to estimate gas hydrate concentrations at Keathley Canyon, northern Gulf of Mexico. Mar. Petr. Geol. 25, 924-931.

Lee, J.Y., Yun, T.S., Santamarina, J.C., Ruppel, C., 2007. Observations related to tetrahydrofuran and methane hydrate for laboratory studies of hydrate-bearing sediments.

Lorenson, T.D., Claypool, G.E., Dougherty, J.A., 2008. Natural gas geochemistry of sediments drilled on the 2005 Gulf of Mexico JIP cruise. Mar. Petr. Geol. 25, $873-883$.

MacDonald, I.R., Guinasso, N.L., Sassen, R., Brooks, J.M., Lee, L., Scott, K.T., 1994. Gashydrate that breaches the sea floor on the continental slope of the Gulf of Mexico. Geology 22, 699-702.

Martin, A.I., 2005. Hydrate-bearing sediments-thermal conductivity. M.S. Thesis, Georgia Institute of Technology, $133 \mathrm{pp}$.

May, D.A., Monaghan, J.J., 2003. Can a single bubble sink a ship? Am. J. Phys. 71, 842-849.

McConnell, D. 2000. Optimizing deepwater well locations to reduce the risk of shallow-water-flow using high-resolution 2D and 3D seismic data. OTC 11973.

McConnell, D., Kendall, B. 2002. Images of the base of gas hydrate stability, Northwest Walker Ridge, Gulf of Mexico. OTC14103. 
Nimblett, J., Ruppel, C., 2003. Permeability evolution during the formation of gas hydrates in marine sediments. J. Geophys. Res. 108, 2420, doi:10.1029/ 2001JB001650.

Paull, C.K., Matsumoto, R., Wallace, P.J., 1996. Gas hydrate sampling on the Blake Ridge and Carolina Rise. Proc. ODP, Init. Repts., 164. Ocean Drilling Program, College Station, TX

Paull, C.K., Ussler III, W., Lorenson, T.D., Winters, W., Dougherty, J.A., 2005. Geochemical constraints on the distribution of gas hydrates in the Gulf of Mexico. Geo-Mar. Lett. 25, 273-280.

Peel, F.J., Travis, C.J., Hossack, J.R., 1995. Genetic structural provinces and salt tectonics of the Cenozoic offshore U.S. Gulf of Mexico; a preliminary analysis. In: Jackson, M.P.A., Roberts, D.G., Snelson, S. (Eds.), Salt Tectonics. AAPG Memoir 65, pp. 153-175.

Pohlman, J.W., Ruppel, C., Hutchinson, D.R., Downer, R., Coffin, R.B., 2008. Assessing sulfate reduction and methane cycling in a high salinity pore water system in the northern Gulf of Mexico. Mar. Petr. Geol. 25, 942-951.

Riedel, M., Collett, T.S., Malone, M.J., Expedition 311 Scientists, 2005. Cascadia margin gas hydrates. Proc. IODP, 311, College Station, TX.

Roberts, H.H., Carney, R.S., 1997. Evidence of episodic fluid, gas, and sediment venting on the northern Gulf of Mexico continental slope. Econ. Geol. 92, 863-879.

Ruppel, C., Dickens, G.R., Castellini, D.G., Gilhooly, W., Lizarralde, D., 2005. Heat and salt inhibition of gas hydrate formation in the northern Gulf of Mexico. Geophys. Res. Lett. 32, L04605.

Santamarina, J.C., Francisca, F., Yun, T.-S., Lee, J.-Y., Martin, A.I., Ruppel, C., 2004 Mechanical, thermal, and electrical properties of hydrate-bearing sediments. AAPG Hedberg Abstracts. <http://www.searchanddiscovery.net/documents/ abstracts/2004hedberg_vancouver/extended/santamarina/santamarina.htm $>$.

Santamarina, J.C, Ruppel, C., 6-10 July 2008a,b. Comprehensive laboratory physical properties measurements on hydrate-bearing sediments and resulting rules of thumb for assessing natural hydrate occurrences. In: Sixth International Conference on Gas Hydrates, Vancouver, BC.

Santamarina, J.C., Ruppel, C., 2008b. The impact of hydrate saturation on the mechanical, electrical, and thermal properties of hydrate-bearing sand, silts, and clay. Proceedings of the $6^{\text {th }}$ International Conference on Gas Hydrates, Vancouver, B.C. Canada, July 6-10, CD-ROM.

Sassen, R., Losh, S.L., Cathles, L., Roberts, H.H., Whelan, J.K., Milkov, A.V., Sweet, S.T. DeFreitas, D.A., 2001. Massive vein-filling gas hydrate: relation to ongoing gas migration from the deep subsurface in the Gulf of Mexico. Mar. Petr. Geol. 18 551-560.

Sassen, R., MacDonald, I.R., 1997. Hydrocarbons of experimental and natural gas hydrates, Gulf of Mexico continental slope. Org. Geochem. 26, 289-293.

Snyder, F.C., Muller, L.K., Dutta, N., Hutchinson, D.R., Hart, P.E., Lee, M.W., Dugan, B. Ruppel, C., Wood, W.T., Coffin, R., Evans, R., Jones, E.H., 2004. Seismic analysis and characterization of gas hydrates in the Northern Deepwater Gulf of Mexico. AAPG Bull. 88 (13). http://www.searchanddiscovery.com/documents/abstracts/ annual2004/Dallas/Snyder.htm (Supplement).
Stern, L.A., Kirby, S.H., Durham, W.B., 1996. Peculiarities of methane clathrate hydrate formation and solid-state deformation, including possible superheating of water ice. Science 273, 1843-1848.

Tréhu, A.M., Bohrmann, G., Torres, M.E., Colwell, F.S. (Eds.), 2003. Drilling Gas Hydrates on Hydrate Ridge, Cascadia Continental Margin. In: Proceedings of ODP, Initial Reports, 204, College Station, TX (Ocean Drilling Program).

Trehu, A.M., Ruppel, C., Dickens, J., Goldberg, D., Holland, M., Riedel, M., Schultheiss, P., Torres, M., 2006. Gas hydrates in marine sediments: lessons from ocean drilling. Oceanography 19, 124-143.

Waite, W.F., Gilbert, L.Y., Winters, W.J., Mason, D.H., 13-16 June 2005. Thermal property measurements in Tetrahydrofuran (THF) hydrate and hydrate-bearing sediment between -25 and $+4{ }^{\circ} \mathrm{C}$, and their application to methane hydrate. In: Proceedings of the Fifth International Conference on Gas Hydrates, vol. 5 paper 5042, Trondheim, Norway1724-1733.

Weinberger, J.L., Brown, K.M., 2006. Fracture networks and hydrate distribution at Hydrate Ridge, Oregon. Earth Planet. Sci. Lett. 245, 123-136.

Weinberger, J.L., Brown, K.M., Long, P.E., 2005. Painting a picture of gas hydrate distribution with thermal images. Geophys. Res. Lett. 32, L04609, doi:10.1029/ 2004 GL021437.

Winters, W.J., Dugan, B., Collett, T.S., 2008. Physical properties of sediments from Keathley Canyon and Atwater Valley, JIP Gulf of Mexico gas hydrate drilling program. Mar. Petr. Geol. 25, 896-905.

Wood, W., Hart, P.E., Hutchinson, D.R., Dutta, N., Snyder, F., Coffin, R.B., Gettrust, J.F. 2008. Gas and gas hydrate distribution around sea.oor seeps in Mississippi Canyon, northern Gulf of Mexico, using multi-resolution seismic imagery. Mar. Petr. Geol. 25, 952-959.

Wood, W., Ruppel, C., 2000. Seismic and thermal investigations of hydrate bearing sediments on the Blake Ridge Crest: a synthesis of ODP Leg 164 results. In: Proceedings of Ocean Drilling Program, Final Reports, 164, pp. 253-264.

Yun, T.S., Francisca, F.M., Santamarina, J.C., Ruppel, C., 2005. Compressional and shear wave velocities in uncemented sediment containing gas hydrate. Geophys. Res. Lett. 32, L10609, doi:10.1029/2005GL022607.

Yun, T.S., Narsilio, G.A., Santamarina, J.C., 2006a. Physical characterization of core samples recovered from Gulf of Mexico. Mar. Petr. Geol. 23, 893-900.

Yun, T.S., Narsilio, G.A., Santamarina, J.C., Ruppel, C., 2006b. Instrumented pressure testing chamber for characterizing sediment cores recovered at in-situ hydrostatic pressure. Mar. Geol. 229, 285-293.

Yun, T.S., Santamarina, J.C., Ruppel, C., 2007. Mechanical properties of sand, silt, and clay containing tetrahydrofuran hydrate. J. Geophys. Res. 112, B04106, doi:10. 1029/2006JB004484.

Xu, H. Dai, J., Snyder, F., Dutta, N., 2004. Seismic detection and quantification of gas hydrates using rock physics and inversion. In: Taylor, C.E., Kwan, J.T. (Eds.), Advances in the Study of Gas Hydrates. Kluwer, New York, pp. 117-139.

Xu, W., Ruppel, C., 1999. Predicting the occurrence, distribution, and evolution of methane gas hydrate in porous marine sediments. J. Geophys. Res. 104, 5081-5096.

Zatsepina, O., Buffett, B.A., 2003. Nucleation of gas hydrate in marine environments. Geophys. Res. Lett. 30, doi:10.1029/2002GL016802. 